\title{
Modelling of three phase svpwm AC-AC converter using unity power factor control
}

\author{
Saidah $^{1}$, Hari Sutiksno ${ }^{2}$, Bambang Purwahyudi ${ }^{1}$ Taufik $^{3}$ \\ ${ }^{1}$ Department of Electrical Engineering,Bhayangkara University, Surabaya, Indonesia \\ ${ }^{2}$ Department of Electrical Engineering, Sekolah Tinggi Teknik Surabaya (STTS), Surabaya, Indonesia \\ ${ }^{3}$ Department of Electrical Engineering, Cal Poly State University, San Luis Obispo, California, USA
}

\begin{tabular}{l}
\hline \hline Article Info \\
\hline Article history: \\
Received Oct 8, 2018 \\
Revised Nov 19, 2018 \\
Accepted May 29, 2019
\end{tabular}

Keywords:

AC-AC converter

Pi controller

Power factor control

SVPWM

\begin{abstract}
This paper introduces the modelling of a novel three phase AC-AC converter with indirect use of a capacitor as DC voltage link. The proposed converter has high efficiency because it uses Space Vector PWM (SVPWM) technique at both rectificier and inverter stages to operate the pulse width modulation in IGBT switches. The novel converter is equipped with a power factor control to shape the rectifier input current waveform to be sinusoidal and to be in phase with the input voltage. To keep the DC voltage stable, the converter utilizes PI controllers. Simulations are conducted for output voltage from 120 to 300 Volts with output frequency ranging from $30 \mathrm{~Hz}$ to $60 \mathrm{~Hz}$. The simulation results show that the converter is able to maintain stable the DC voltage and current. Furthermore, the model demonstrates the benefits of proposed converter in terms of acquiring high input power factor and sinusoidal current waveform at the output side of the inverter.
\end{abstract}

Copyright (C) 2019 Institute of Advanced Engineering and Science. All rights reserved.

\section{Corresponding Author:}

Saidah,

Departement of Electrical Engineering,

Bhayangkara University,

Ahmad Yani 114, Surabaya, Jawa Timur, Indonesia.

Email: saidah@ubhara.ac.id and saidahbaisa@gmail.com

\section{INTRODUCTION}

AC power sources are frequently needed in industry to operate devices, with different amplitude and frequency from that provided by the grid. A power electronic circuit known as a three-phase AC-AC converter is used to convert a fixed $\mathrm{AC}$ voltage to a variable $\mathrm{AC}$ voltage with adjustable frequency. Some common applications of such converter that are widely used in industry include adjustable-speed drives, AC-AC transmission, uninterruptible power supplies (UPS) and renewable energy conversion systems [1]. However, the variable speed drive systems for induction motors constitute an important area of $\mathrm{AC}-\mathrm{AC}$ conversion sue to the fact that it currently accounts for about $50 \%$ of electricity consumption [2]. The most popular of approach for AC-AC converter modelling involves the use of a DC-link component by employing either a capacitor (as a DC voltage source) or an inductor (as a DC current source). This type of converter is widely used in industry and is known as an indirect frequency converter with a DC energy storage element, and has been investigated extensively for many years [3]. This AC-AC converter has the main advantage that both rectification and inverter are largely separated for control process. On the other hand, the approach has inherent drawback of having DC link energy storage component that is relatively large in physical volume. To address the aforementioned issue with the physical size of the DC link component, some researchers have developed other types of AC-AC converters without using the DC-link component. These converters are called a direct power-frequency converter. There are many direct power frequency converter topologies with the most common one is the Matrix Converter (MC). This converter has no DC energy storage elements and basically consists of an array of static power switches connected between the source and load terminals. For 
good performance direct frequency converters must have small capacitors and inductors, such as those used in their high frequency component filters or small regenerative $\mathrm{AC}$ energy storage. However MC has some disadvantages. The voltage transfer ratio is limited to 0.866 to obtain sinusoidal output waveforms [4-6]. It also requires more semiconductor devices compared to conventional $\mathrm{AC}-\mathrm{AC}$ indirect converters. Moreover, $\mathrm{MC}$ is sensitive to disturbances at the input voltage to the system [7]. The MC has been observed to possess higher level of Total Harmonic Distortion (THD) compared to indirect converters [8].

To accomplish the most desirable operation, the AC-AC converters must be able to generate load voltages with arbitrary amplitude and frequency, produce sinusoidal source and load currents further implying the provision of unity power factor for any load, accommodate bidirectional power flow through the converters, and finally a simple and compact power circuit [9]. Various methods are used by researchers to improve power factor, regulate inverter output voltage and maintain DC voltage at the desired value. The researchers previously used filters on the network side to obtain unity power factor $[10,11]$. There are also researchers who use the technique of nonlinear backstepping control [12, 13], combined PID and PI Control [14] and Voltage Oriented Controls (VOC) with estimation of active power and reactive power [15]. while the control method of this paper only consists of a PI control to maintain a stable DC voltage and unity power factor control so the model of the AC-AC converter becomes simpler.

This paper describes a proposed three phase AC-AC converter to convert 220 Volts, $50 \mathrm{~Hz}$ input into a variable voltage from 120 to 300 Volts with variable frequency from $20 \mathrm{~Hz}-60 \mathrm{~Hz}$ which have never been discussed in previous papers. This converter belongs to the indirect converter type and it is suitable to operate asynchronous motors (induction motors) with various loads where expected speed, thus frequency and variable voltage are needed. The proposed AC-AC converter is equipped with power factor controller to keep a unity power factor and obtain sinusoidal input current from the grid as well as sinusoidal ouput current. The converter offers high efficiency because it uses Space Vector PWM (SVPWM) to handle the pulse width modulation in its IGBT switch components.

\section{MODEL OF AC-AC CONVERTER}

\subsection{Proposed AC-AC converter model}

Figure 1 shows the proposed three Phase AC-AC converter model. The converter is an indirect converter with DC-Link capacitor as the energy storage element. The converter model consists of a rectifier, DC-Link capacitor and an inverter that implements the Space Vector Modulation (SVM) technique. The SVM control technique is used for both the rectifier and inverter feeding the induction motor. The SVM technique is chosen due to its more prevalent use than all other conventional techniques as the technique offers improved DC bus utilization, lower harmonics, less switching losses, and higher overall converter's efficiency [16]-[19]. The main task of the SVM technique is to calculate the duty cycles and define the switching pattern.

In the proposed converter and as illustrated in Figure 1, the novelty lies on the unity power factor control employed in the converter that will maintain the input power factor to the rectifier stage close to one. Consequently, the power factor control keeps the source current in the same phase as the voltage.

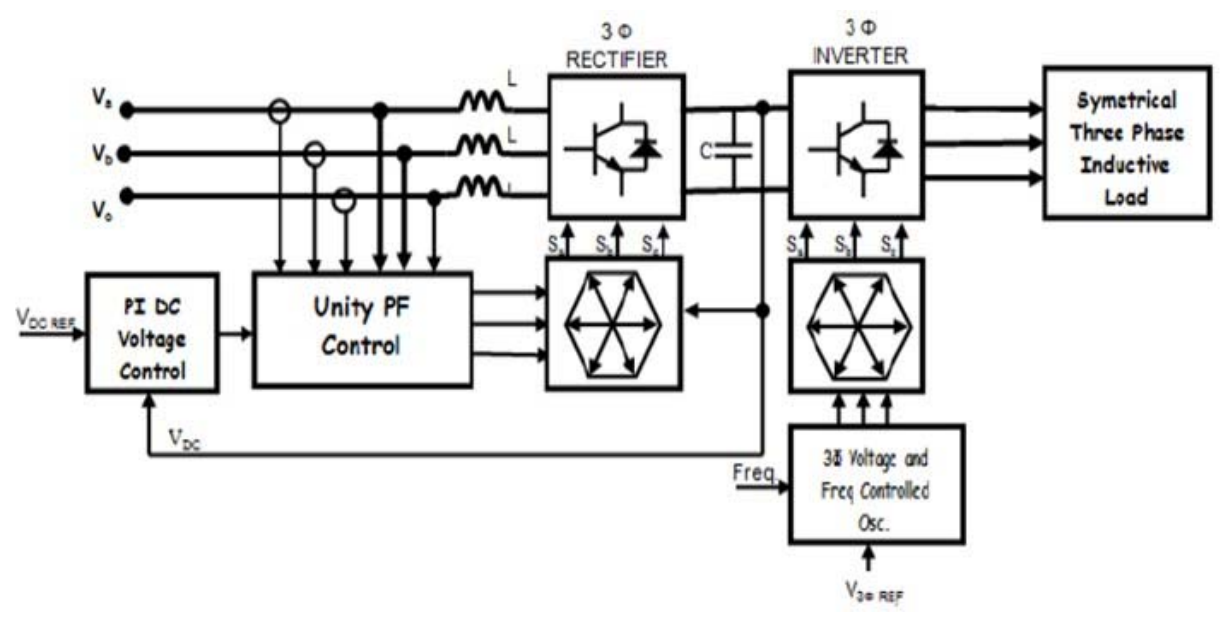

Figure 1. Proposed of AC-AC converter

Int J Pow Elec \& Dri Syst Vol. 10, No. 4, Dec 2019 : $1823-1832$ 


\subsection{Unity power factor control}

Unity power factor occurs when the difference between voltage angle $\theta_{\mathrm{V}}$ and current angle $\theta_{\mathrm{I}}$ is zero degrees. In other words, it is established when voltage and current waveforms are in phase.

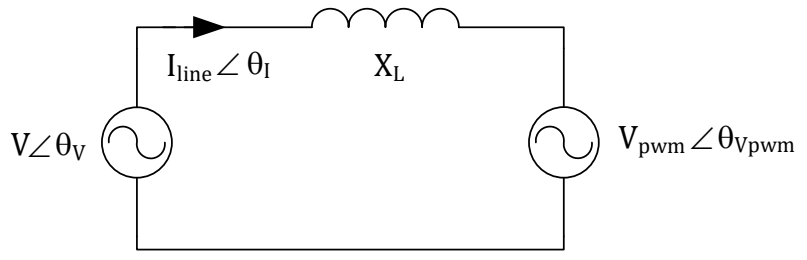

Figure 2. Equivalent circuit of the converter from the ac source side

The current regulator can be realized by making a calculation process to generate the desired PWM voltage, so that the current flowing in the inductor can be determined, as shown in Figure 2. In a power converter, if it is assumed that the sampling period is Ts, the inductor resistance is negligible, and the source input voltage at the sampling interval is considered constant, then the current flowing in the inductor can be determined according to the equation as follows:

$$
V\left(t_{n}\right)-V_{P W M}\left(t_{n}\right)=L \frac{\Delta i}{\Delta t}=L \frac{i\left(t_{n}+T_{s}\right)-i\left(t_{n}\right)}{T_{s}}
$$

where: $V\left(t_{n}\right)$ is the source voltage at $\mathrm{t}=\mathrm{tn}$

$V_{P W M}\left(t_{n}\right)$ is the PWM voltage on the AC side of the converter Equation (1) can be written as:

$$
V_{P W M}\left(t_{n}\right)=V\left(t_{n}\right)-\frac{L}{T_{s}}\left[i\left(t_{n}+T_{s}\right)-i\left(t_{n}\right)\right]
$$

Here it appears that the magnitude of the inductor current that will flow at time $t=t n+$ Ts can be determined by giving the PWM voltage according to the instantaneous current equation proportional to the voltage. This current setting provides the possibility to obtain a sinusoidal current waveform with a power factor equal to one. If the current is a sinusodal and has a phase equal to its voltage, then the reference current may be defined as:

$$
i\left(t_{n}+T_{s}\right)=k V\left(t_{n}+T\right)
$$

where $\mathrm{k}$ is a constant whose magnitude depends on the current to be streamed. This reference current does not change rapidly compared to the sampling period. Therefore, the current can be predicted through the previous value approach, as shown in Figure 3, as:

$$
\begin{aligned}
& i\left(t_{n}+T_{s}\right) \approx i(t)+\frac{i\left(t_{n}\right)-i\left(t_{n}-T_{s}\right)}{T_{s}} \cdot T \\
& \text { Or } i\left(t_{n}+T_{s}\right) \approx 2 i\left(t_{n}\right)-i\left(t_{n}-T_{s}\right)
\end{aligned}
$$

according to equation (3), the reference current of equation (5) can be expressed as follows:

$$
i\left(t_{n}+T_{s}\right) \approx 2 k V\left(t_{n}\right)-k V\left(t_{n}-T_{s}\right)
$$


By combining equations (2) and (6), the reference voltage can be obtained as:

$$
V^{\prime}\left(t_{n}\right)=\left(1-\frac{2 k L}{T_{s}}\right) V\left(t_{n}\right)+\frac{k L}{T_{s}} V\left(t_{n}-T_{s}\right)+\frac{L}{T_{s}} i\left(t_{n}\right)
$$

Equation (7) denotes the PWM voltage to be raised so that the current flowing in the inductor is $\mathrm{k} \cdot \mathrm{V}(\mathrm{t})$. Figure 4. shows the current regulator diagram of PWM converter with input voltage $\mathrm{V}(\mathrm{t})$, channel currenti( $\mathrm{t})$, and $\mathrm{k}$ factor. This current regulator is realized in the calculation process by using a microprocessor, together with the PWM signal generation process. With the current regulator the current waveform will be the same as the voltage-shaped sinusoidal waveform and with the same phase. Figure 4 illustrates the vector diagram of the system.

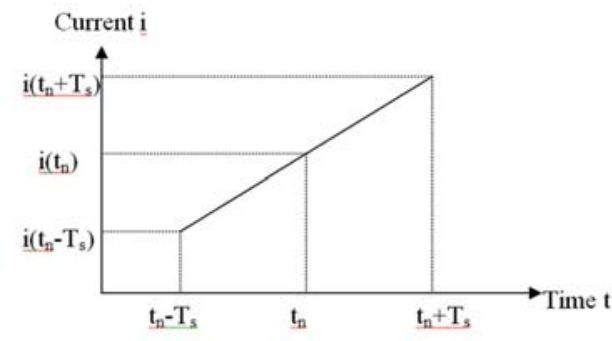

Figure 3. The reference current at the end of each period

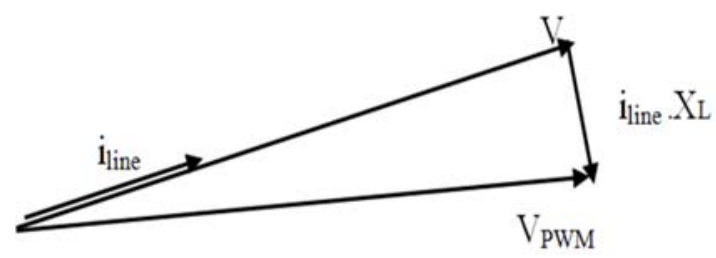

Figure 4. Vector diagram of the converter from the AC source side

\section{RESULTS AND DISCUSSION}

The proposed AC-AC converter performance is simulated with Matlab/Simulink software. In the simulation, the three-phase source voltage is set at $220 \mathrm{~V} / 50 \mathrm{~Hz}$, the DC voltage is 1000 Volts and the sampling frequency is $10 \mathrm{kHz}$. The desired AC output voltage varies with variable frequency and different load impedance. The simulation is done on the output voltage from 120 to 300 Voltswith output frequency being varied from 20 to $60 \mathrm{~Hz}$, while observing the power factor, DC voltage and current, the output voltage and current waveforms. The rectifier in the simulation follows the requirements of three-phase voltage source $220 \mathrm{~V} / 50 \mathrm{~Hz}$ with amplitude $\sqrt{ } 2 \times 220=311$ Volts, DC Voltage of 1000 Volts, and the sampling frequency is $10 \mathrm{kHz}$. To evaluate the performance of the proposed converter, six different cases were simulated and analyzed. Previous researchers conducted evaluations of converter performance for only one case. Table 1 list the inverter specifications for each of these cases.

Table 1. Inverter specifications

\begin{tabular}{ccccc}
\hline \multirow{2}{*}{ Case } & $\begin{array}{c}\text { Output } \\
\text { Voltage }\end{array}$ & $\begin{array}{c}\text { Amplitude } \\
\text { Voltage }\end{array}$ & $\begin{array}{c}\text { Output } \\
\text { Frequency }\end{array}$ & Load \\
\hline 1 & 220 Volt & 311 Volt & $30 \mathrm{~Hz}$ & $6+\mathrm{j} 8$ ohm \\
2 & 250 Volt & 353 Volt & $50 \mathrm{~Hz}$ & $10+\mathrm{j} 10$ ohm \\
3 & 120 Volt & 170 Volt & $60 \mathrm{~Hz}$ & $6+\mathrm{j} 8$ ohm \\
4 & 120 Volt & 170 Volt & $50 \mathrm{~Hz}$ & $10+\mathrm{j} 10$ ohm \\
5 & 120 Volt & 170 Volt & $30 \mathrm{~Hz}$ & $6+\mathrm{j} 8$ ohm \\
6 & 300 Volt & 424 Volt & $30 \mathrm{~Hz}$ & $10+\mathrm{j} 10$ ohm \\
\hline
\end{tabular}

Case 1. DC voltage source 1000 Volts, voltage amplitude of inverter output 311 Volts, output frequency 30 $\mathrm{Hz}$ and load impedance $6+j 8 \mathrm{ohm}$.

Simulation results are shown in Figures 5-8. Figures 5 and 6 show that DC Current and DC Voltage are both stable respectively with steady state DC voltage of 1000 Volts. The source current and voltage of the rectifier have the same phase as shown at Figure 7.,which results in unity power factor. The rectifier source voltage amplitude of 311 Volts at frequency $50 \mathrm{~Hz}$ is successfully converted to $311 \mathrm{Volts}$ at $30 \mathrm{~Hz}$ frequency sinusoidal output waveform, as depicted in Figure 8.

Int J Pow Elec \& Dri Syst Vol. 10, No. 4, Dec 2019 : 1823 - 1832 


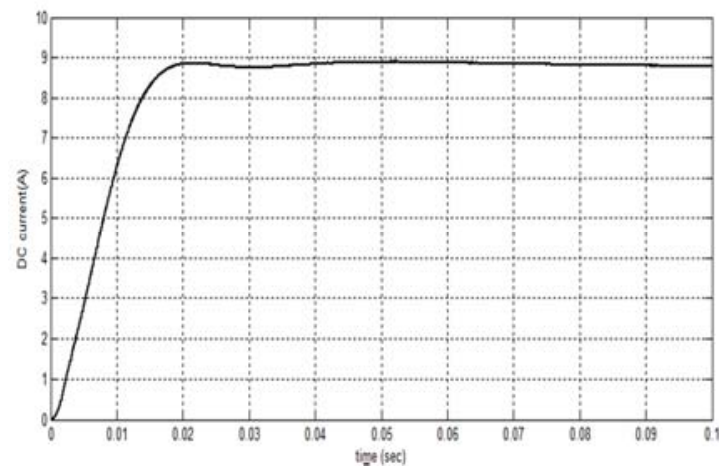

Figure 5. DC current, case 1

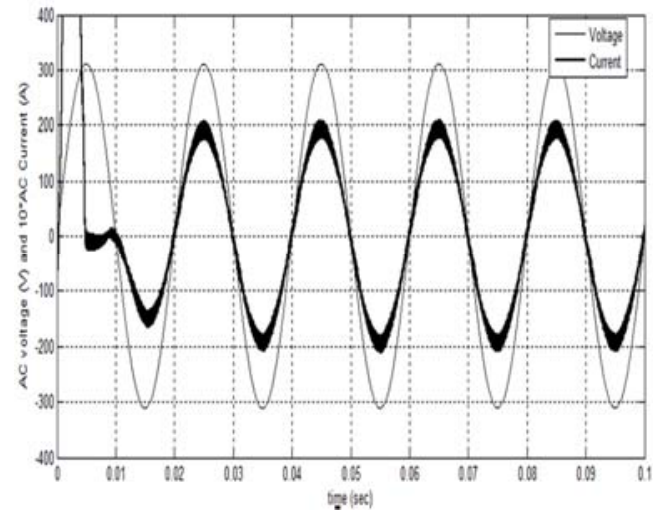

Figure 7. Amplitude of voltage and current at input of rectifier, case 1

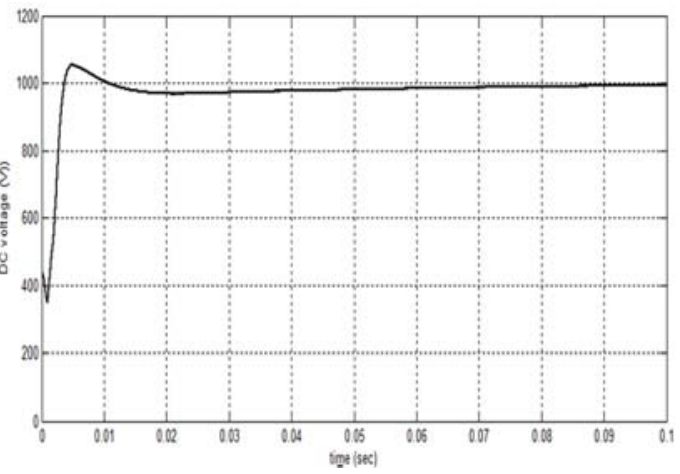

Figure 6. DC voltage, case 1

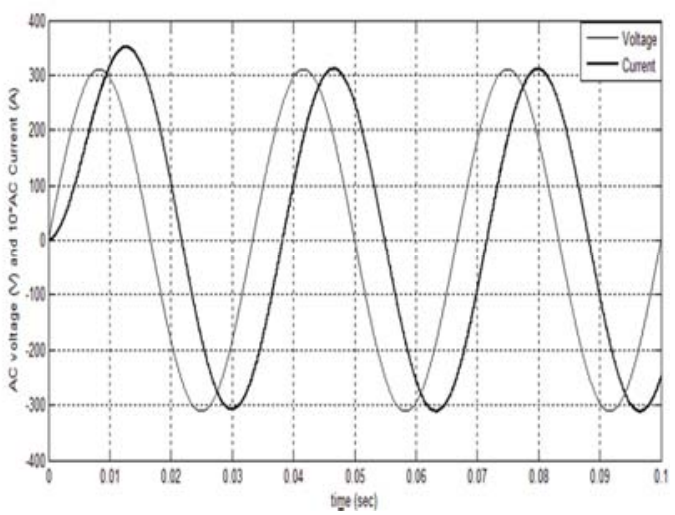

Figure 8. Amplitude of voltage and current at output of inverter, case 1

Case 2. DC voltage source 1000 Volts, voltage amplitude of inverter output 353 Volts, output frequency 50 $\mathrm{Hz}$ and load impedance $10+\mathrm{j} 10 \mathrm{ohm}$.

Simulation results are presented in Figures $9-12$. As observed in the previous case, the result shows stable DC current and DC Voltage at 1000 Volt as illustrated in Figures 9 and 10 respectively. The source current and voltage of the rectifier have the same phase, which again proves the unity power factor, as shown in Figure 11. The rectifier source voltage amplitude of 311 Volts at frequency $50 \mathrm{~Hz}$ is again converted well to 353 Volts at the same frequency $50 \mathrm{~Hz}$, as seen in Figure 12, while the output current waveform is sinusoidal as desired.

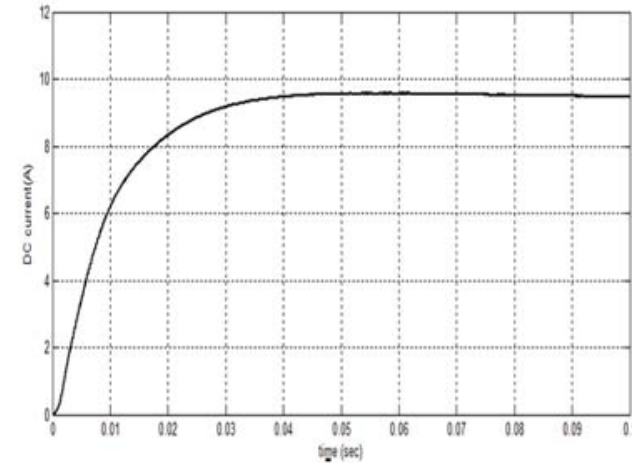

Figure 9. DC current, case 2

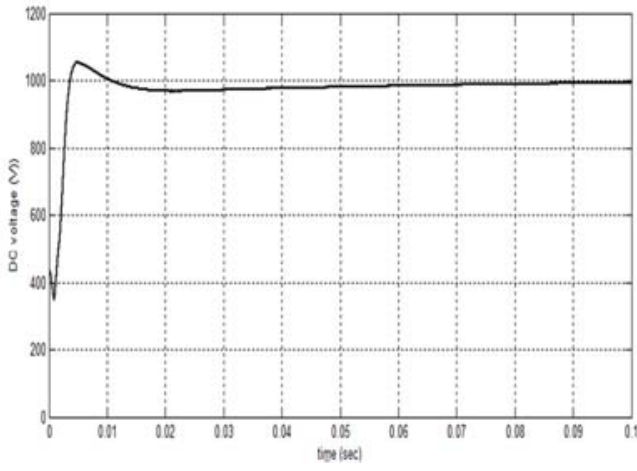

Figure 10. DC voltage, case 2 


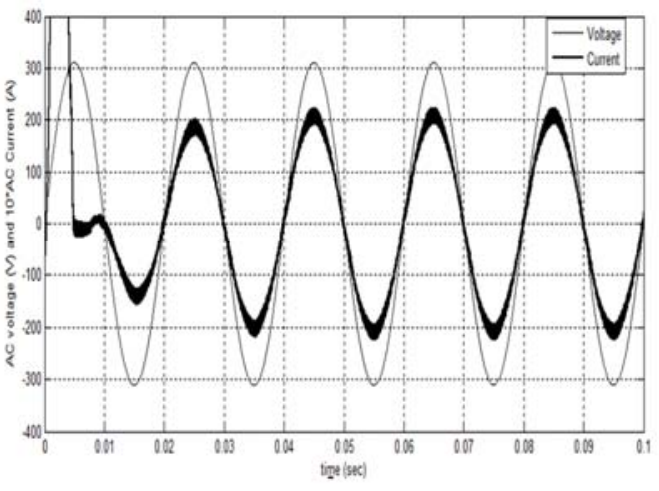

Figure 11. Amplitude of voltage and current at iinput of rectifier, case 2

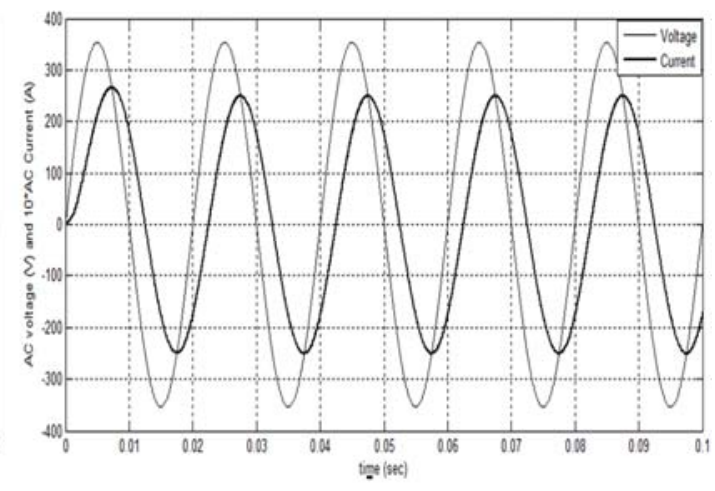

Figure 12. Amplitude of voltage and current at output of inverter, case 2

Case 3. DC voltage source 1000 Volts, voltage amplitude of inverter output 170 Volts, output frequency 60 $\mathrm{Hz}$ and load impedance $6+j 8 \mathrm{ohm}$.

Simulation results as presented in Figures 13-16 again showstable DC current and DC Voltage at 1000 Volt as illustrated in Figures 13 and 14 respectively. The unity power factor has also been achieved between the source current and voltage of the rectifier as shown in Figure 15. The rectifier source voltage amplitude of 311 Volts at frequency $50 \mathrm{~Hz}$ is converted to 170 Volts at the same frequency $60 \mathrm{~Hz}$, as depicted in Figure 16. , while again achieving the desired sinusoidal output current waveform.

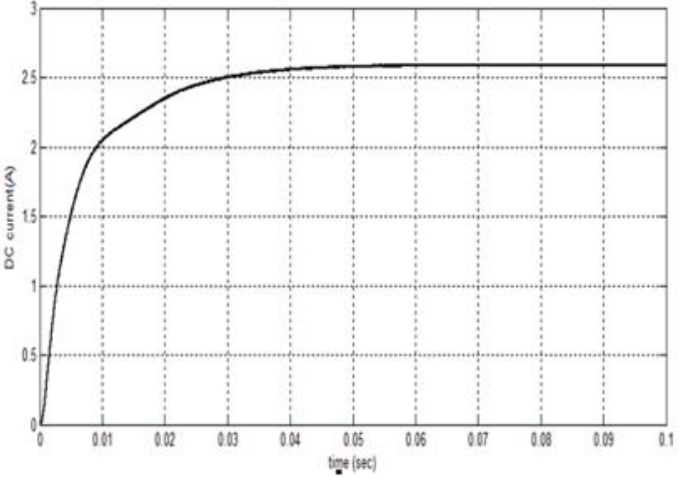

Figure 13. DC current, case 3

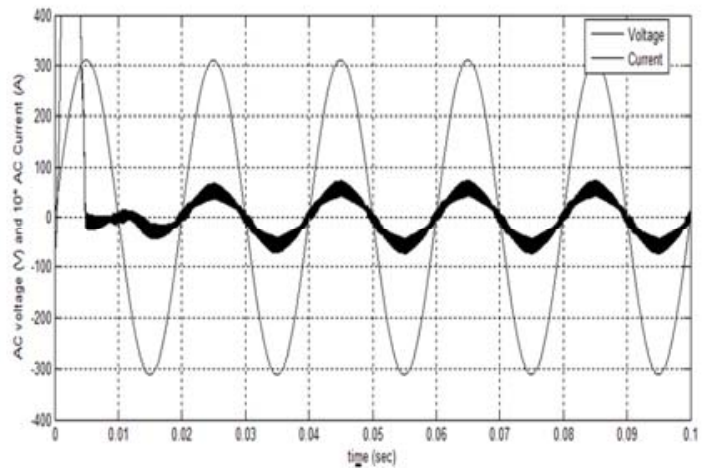

Figure 15. Amplitudeof voltage and current at input of rectifier, case 3

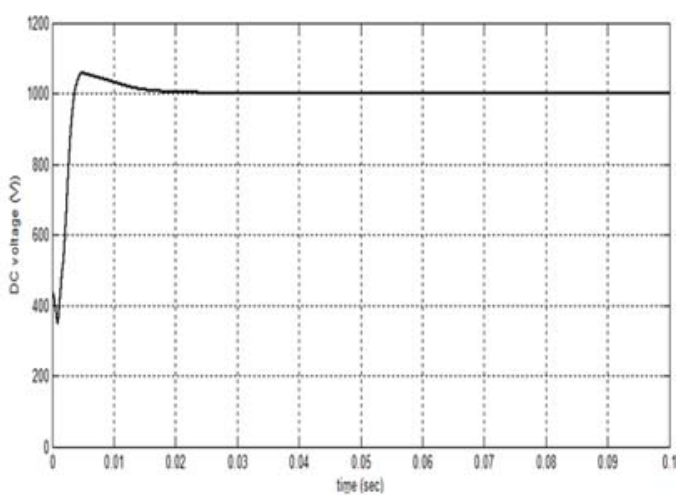

Figure 14. DC voltage, case 3

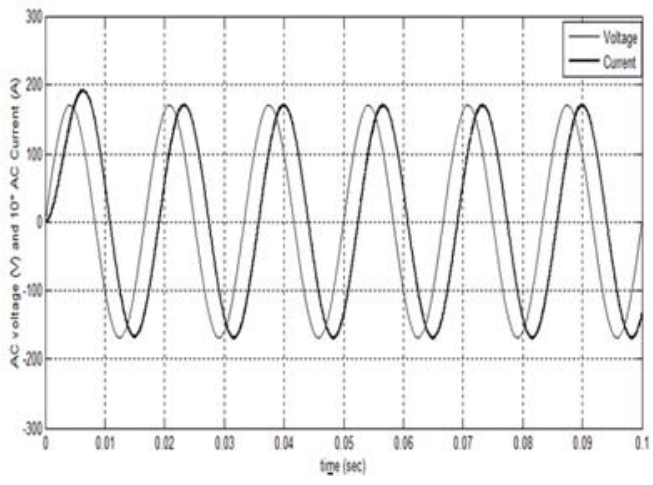

Figure 16. Amplitude of voltage and current at output of inverter, case 3 
Case 4. DC voltage source 1000 Volts, voltage amplitude of inverter output 170 Volts, output frequency 50 $\mathrm{Hz}$ and load impedance $10+j 10 \mathrm{ohm}$.

Simulation results are shown in the Figure 17-20. Figure 17 shows stable DC current and Figure 18 shows DC voltage is stable at 1000 Volts. The source current and voltage of rectifier again shows that they are in phase as shown at Figure 19. The conversion of source voltage with amplitude of $311 \mathrm{Volts}$ at $50 \mathrm{~Hz}$ takes place successfully to sinusoidal 170 Volts at $50 \mathrm{~Hz}$ as presented in Figure 20.

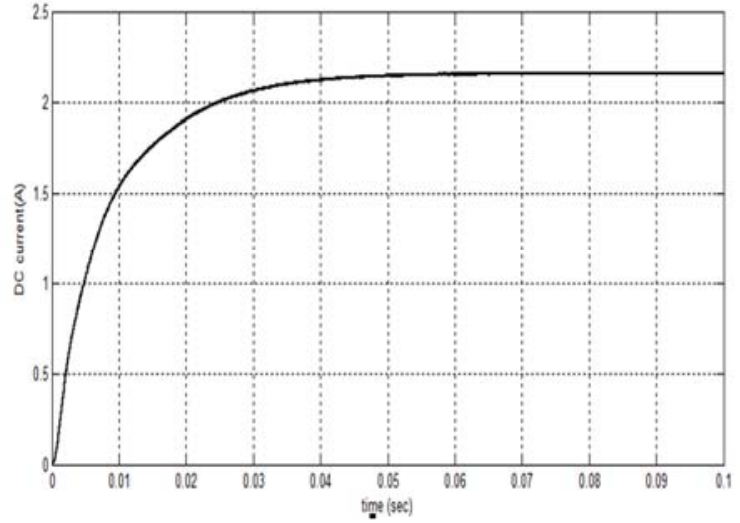

Figure 17. DC current, case 4

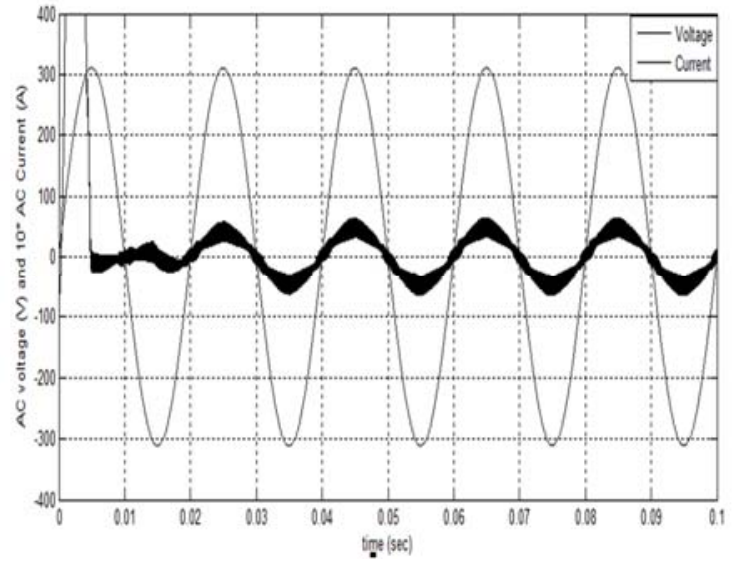

Figure 19. Amplitude of voltage and current at input of rectifier, case 4

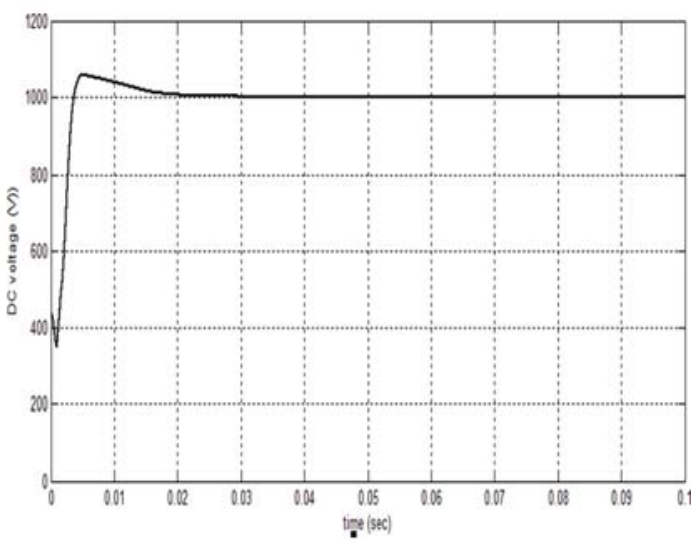

Figure 18. DC voltage, case 4

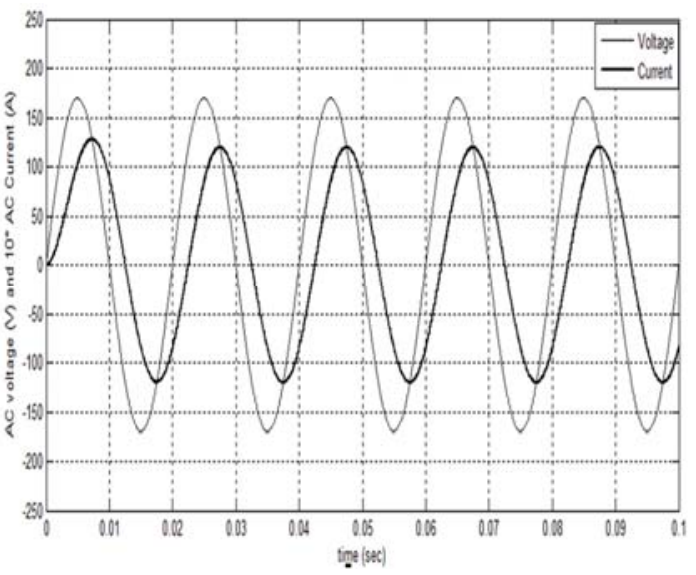

Figure 20. Amplitude of voltage and current at output of inverter, case 4

Case 5. DC voltage source 1000 Volts, voltage amplitude of inverter output 170 Volts, output frequency 30 $\mathrm{Hz}$ and load impedance $6+j 8 \mathrm{ohm}$.

Results of this case are in agreement with the previous ones. As illustrated in Figures 21 and 22, both DC current and DC voltage are stable. The source current is also in phase with the source voltage of rectifier, making the input power factor unity, see Figure 23. Sinusoidal output waveform is achieved after the conversion of source voltage amplitude of rectifier at 311 Voltsand $50 \mathrm{~Hz}$ to $170 \mathrm{Volts}$ at $30 \mathrm{~Hz}$ took place, as depicted in Figure 24. 


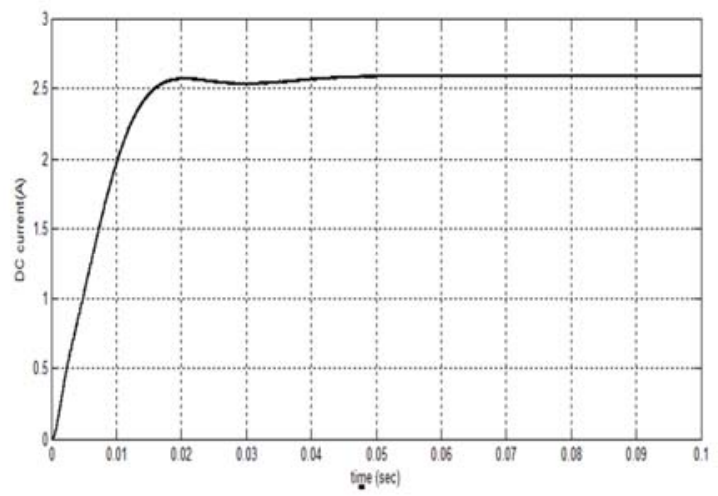

Figure 21. DC current, case 5

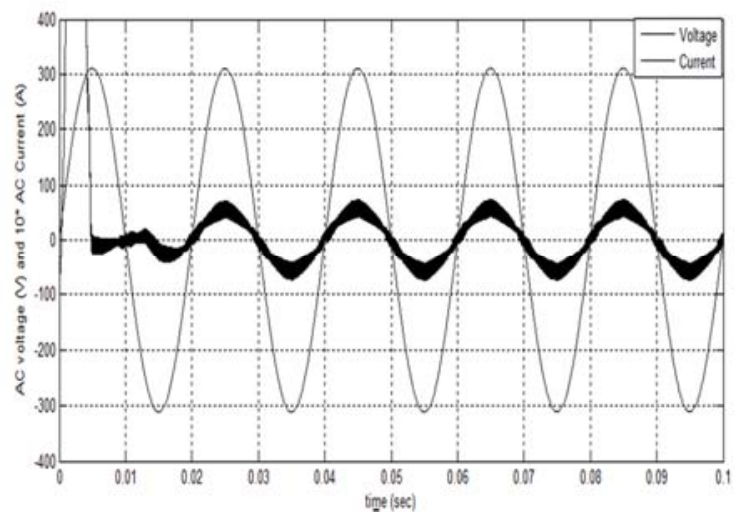

Figure 23. Amplitude voltage and current at input of rectifier, case 5

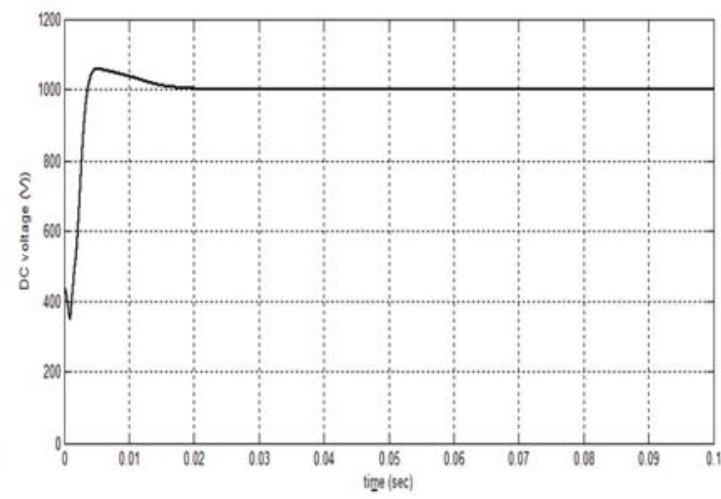

Figure 22. DC voltage, case 5

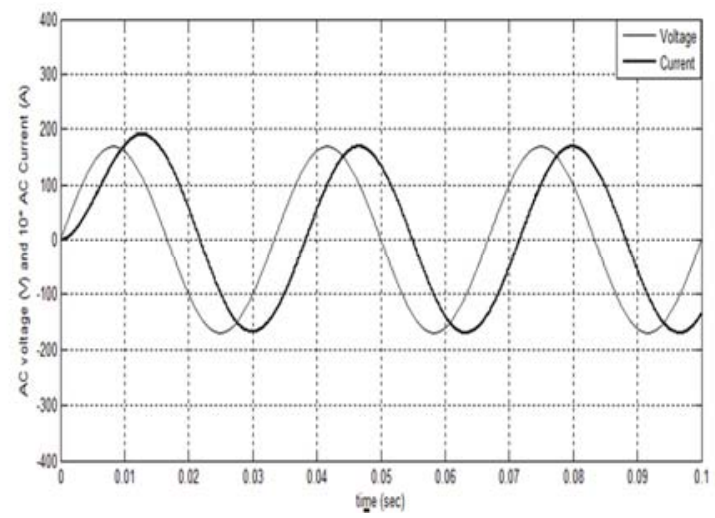

Figure 24. Amplitude voltage and current at output of inverter, case 5

Case 6. DC voltage source 1000 Volts, voltage amplitude of inverter output 300 Volts, output frequency 30 $\mathrm{Hz}$ and load impedance $10+\mathrm{j} 10 \mathrm{ohm}$.

Simulation results for this case are consistent with those observed in the previous cases. Stable DC current and DC voltage are shown in Figure 25 and 26, and unity power factor as the result of in phase behavior of source current and voltage can be observed in Figure 27. The converter is also able to convert successfully 311 Volts at $50 \mathrm{~Hz}$ at the rectifier to sinusoidal 300 Volts at $30 \mathrm{~Hz}$ at converter's output in Figure 28.

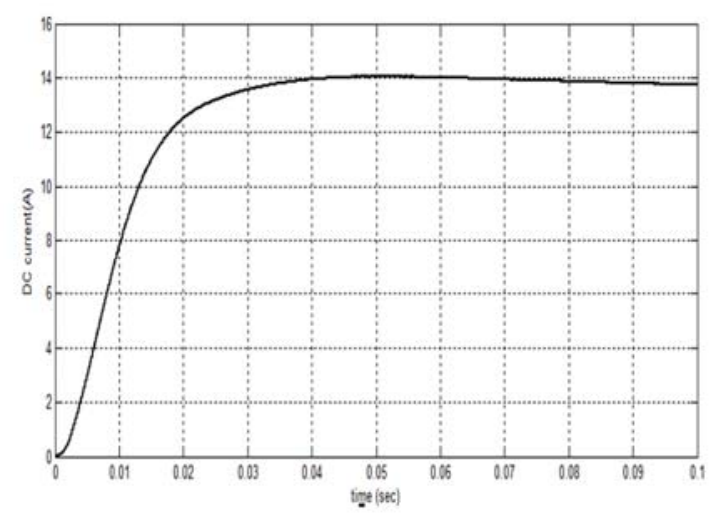

Figure 25. DC current, case 6

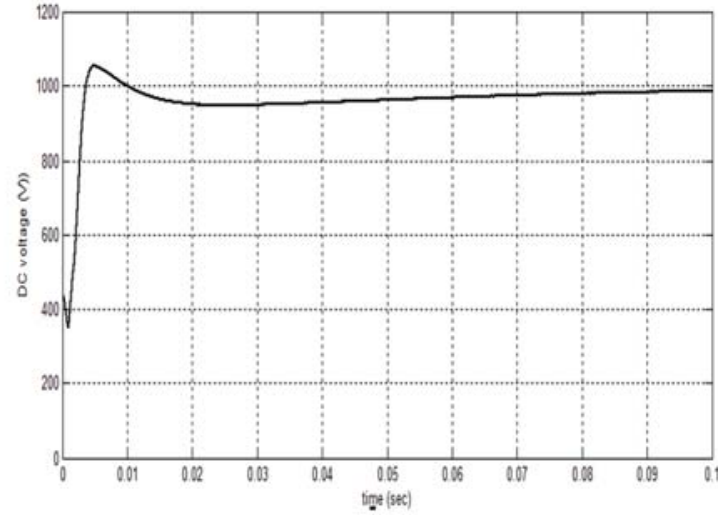

Figure 26. DC voltage, case 6 


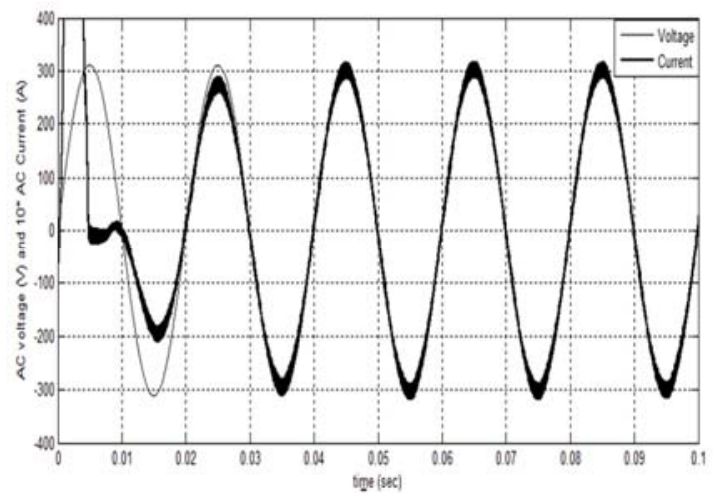

Figure 27. Amplitude voltage and current at input of rectifier, case 6

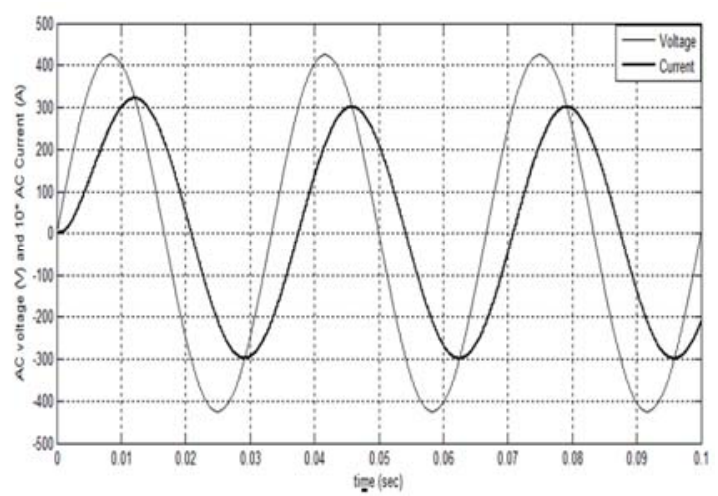

Figure 28. Amplitude voltage and current at output of inverter, case 6

\section{CONCLUSION}

This paper presents a proposed three-phase AC-AC converter using a capacitor as an energy storage element. A model of the proposed converter was developed which utilizes power factor control to ahieve close to unity power factor. The proposed converter model also includes PI controllers to keep the DC voltage stable. The proposed AC-AC converter was tested using simulation to produce inverter output voltages ranging from 120 Volts to 300 Volts with frequencies between $30-60 \mathrm{~Hz}$. Simulation results of six different system scenarios further exhibit the ability of proposed converter in successfully changing the inverter output voltage at different frequencies and varying load. All of these were achieved by the proposed converter while maintaining unity power factor, stable DC voltage and DC current, and sinusoidal inverter output voltage waveform.

\section{ACKNOWLEDGEMENTS}

The authors would like to express their gratitude to God, beloved family, and teachers. Special thanks are due to the Directorate General of Higher Education (Direktorat Jenderal Pendidikan Tinggi) that provided the funding for this research.

\section{REFERENCES}

[1] B. Wu, "High-power Converters and AC Drives", Piscataway, NJ: IEEE/Wiley, 2006.

[2] Boldea I, Nasar SA, "Electric drives", 2nd edn. CRC press, Boca Raton, 2006.

[3] Kolar JW, FriedliT,KrismerF,Round SD, “The essence of three-phaseAC/AC converter systems”, In: Proceedings of power electronics andmotion control conference, EPE-PEMC'08,Pozna'n, Poland, pp 27-42, 2008

[4] Thomas Friedli and Johann W. Kolar, "Comprehensive Comparison of Three-Phase AC-AC Matrix Converter and Voltage DC-Link Back-to-Back Converter Systems",2011.

[5] Johann W. Kolar, Thomas Friedli, Jose Rodriguez and Patrick W. Wheeler, "Review of Three-Phase PWM AC-AC Converter Topologies", IEEE Transactions On Industrial Electronics, vol. 58, no. 11, 2011.

[6] HulusiKaraca and RamazanAkkaya, "Modeling, Simulation and Analysis of Matrix Converter Using Matlab\& Simulink", International Journal of Modeling and Optimization, vol. 2, no. 3, 2012.

[7] L. Huber and D. Borojevic, "Space vector modulated three-phase to three-phase matrix converter with input power factor correction," IEEE Trans. Ind. Appl, vol. 31, no. 6, 1995.

[8] C.Kalaiselvi, M.Bhuvaneswari, A.DivyaVinoth Raja, "Comparison of Three Phase Voltage Back to Back Converter and Matrix Converter", International Journal of Innovative Research in Computer and Communication Engineering, vol. 2, no 11, 2014.

[9] Wheeler PW, Rodriguez J, Clare JC, Empringham L, Weinstejn, “A Matrix converters: a technology review”, IEEE Trans Ind Electron, vol. 49(2), pp. 276-288, 2002.

[10] K. Kaviarasu, T. Kamalraj, "An Improved Single Phase AC-AC Converter With Quasi-Z-Source Technique”, International Journal For Technological Research In Engineering vol. 1, no 9, 2014.

[11] Edison R. C. da Silva Euzeli C. dos Santos Jr. Antônio I. Lacerda, "Coupled-Inductor AC-to-AC Converters Having Improved Input Power Factor, Simple Control, and Variable Output Frequency”, IEEE, 2010.

[12] A.Ait elmahjoub, A.Ailane, A.Abouloiafa, A.Essadki, M.Rachik, E.Labriji, "A Non-linear Controller for SinglePhase AC-AC Power Converter to meet UPS Performance Index", 2012. 
[13] Abderrahim El Fadili, Fouad Giri, Abdelmounime El Magri, Luc Dugard, "Nonlinear controller for Doubly Fed Induction Motor with bi-directional AC/DC/AC converter", 2013, 11th IFAC International Workshop on Adaptation and Learning in Control and Signal Processing July 3-5, 2013. Caen, France

[14] Suwat Kitcharoenwat, Mongkol Konghirun, and Anawach Sangswang, Non-members, "A Novel Single Phase ACAC Converter with Power Factor Control", Ecti Transactions On Electrical Eng., Electronics, And Communications, vol. 11, no.1 2013

[15] F.J. Maseda, O. Barambones, A.J. Garrido and I. Martija, "A Sensorless AC-DC-AC Converter with Sliding Mode Controller for Induction Motors Drives", 2014.

[16] Saidah, MH Purnomo, M Ashari,"High Performance of Nonlinear Active Rectifier Voltage and Power Factor Control Using Feedback Linearization”, International Review of Electrical Engineering (IREE), vol. 8, no 2, pp. 568-574, 2013.

[17] Saidah, B. Purwahyudi, Kuspijani, "Control Strategy for PWM Voltage Source Converter Using Fuzzy Logic for Adjustable Speed DC Motor”, IJPEDS, vol. 8, pp. 51-58, 2017.

[18] Hongwu She, Hua Lin, Bi He, Xingwei Wang, LiminYue, and Xing An, "Implementation of Voltage-Based Commutation in Space-Vector-Modulated Matrix Converter", IEEE Transactions on Industrial Electronics, vol. 59 , no. $1,2012$.

[19] Saidah, MH Purnomo, M Ashari, "Advanced Control Of Active Rectifier Using Switch Function And Fuzzy Logic For Nonlinear Behaviour Compensation”, JATIT, 156 -161, 2012.

\section{BIOGRAPHIES OF AUTHORS}
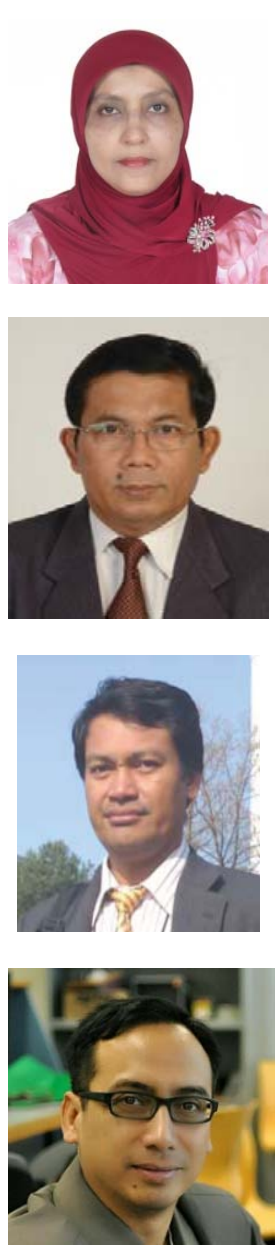

Saidah received her bachelor, master and Ph.D degree from Institut Teknologi Sepuluh Nopember (ITS) Surabaya in 1985, 2005 and 2013 respectively. She has been the faculty member in Bhayangkara University in Surabaya since 2006. Her research interests are on the use of artificial intelligent for power electronics, control and electric drives applications.

Hari Sutiksnoreceived his bachelor, master and Ph.D degree from Institut Teknologi Sepuluh Nopember (ITS) Surabaya in 1981, 2001 and 2013 respectively. He joined Sekolah Tinggi Teknik Surabaya (STTS) in Surabaya since 1981. His research interest focuses on the use of artificial intelligent for power electronics control and electric drives applications.

Bambang Purwahyudi received his bachelor, master and doctor degree from Institut Teknologi Sepuluh Nopember (ITS) Surabaya, Indonesia, in 1995, 2005 and 2013 respectively. He has joined Bhayangkara University Surabaya, Indonesia, since 2000. He got publications in several National and International journals and conferences. His areas of interest are simulation and design of power electronics, power quality, renewable energy, and artificial intelligent application to power electronics and drive.

Taufik received his Bachelor of Science in Electrical Engineering with minor in Computer Science, Northern Arizona University, May 1993, Master of Science in Electrical Engineering and Computer Science, University of Illinois at Chicago, May 1995, and Doctor of Engineering in Electrical Engineering, Cleveland State University, May 1999. He joined the electrical engineering department at Cal Poly State University, California, USA in 1999 where he is currently a Professor and Director of Electric Power Institute. He is Senior Member of the Instituteof Electrical and Electronics Engineers (IEEE), and Member of American Society of Engineering Education (ASEE). His research interests encompass the area of Power Electronics, Power Systems, Smart Grid, Renewable Energy, and Power Quality. 